\title{
VIBRATION ANALYSIS OF FUNCTIONALLY GRADIENT DENTAL IMPLANT
}

\author{
Saeed Asiri
}

Mechanical Engineering Department, Engineering College, King Abdulaziz University, Saudi Arabia

Email: saeed@asiri.net

\begin{abstract}
A dental implant is considered as the best treatment when dealing with the loss of teeth. It gives beautiful results and can last longer than most of other treatments. Osseointegration period is a critical period for implant stability. The material used for dental implants is one of the most important factors affecting the stability so using Functionally Gradient Material (FGM) can help improve the stability. In this study, several models for dental implants were analyzed by ANSYS 15.0 APDL. The FGM was considered in three models. The same materials, Ti-HA, were used in all of them but with different geometrical parameters. The natural frequency and mode shapes were extracted for all models and then the harmonic analysis was performed to study the frequency responses for the different models. It was noticed that all the extracted results for FGM vary between the two basic materials, and it is affected by the concentration of each. It is firmly believed that FGM is the future of dental implants due to its ability to design a specific material property for more stability.
\end{abstract}

\section{Keywords: Functionally Gradient Material, FGM, Dental Implant, Vibrations, Modal Analysis, Harmonic Analysis, FEM.}

\section{INTRODUCTION}

The Functionally Gradient Material (FGM) is a pioneering composite material that follows a predetermined law of the microstructure and composition of the material. The change in structure and composition varies over volume either randomly or strategically, which results in changes in the properties of the material for performing certain functions. These properties depend on the spatial position in the structure. FGM can be designed to modify the response of the material to meet the design criteria. The FGM, which contains ceramic on the outer surface and metal on the inner surface, eliminates the rapid change between coefficients of thermal expansion, offers thermal protection, and provides load carrying capability. This is because the material constituents of an FGM change slowly through the thickness, which further results in the elimination of stress concentrations from sudden changes in material properties. A dental implant is considered the best treatment when dealing with the loss of teeth. It gives esthetic results and can last longer than most other treatments. In addition, it is associated with minimal failures (2-3\%), and many people consider dental implants as the first-choice treatment. The geometrical parameters of the implant have a major influence on the stress distribution within the surrounding jawbone. [1-9]. Astrand et al. showed that the survival rate in soft-quality bone may be increased by using a tapered implant [10]. 
One of the major areas to be studied for dental implant stability is the material type. It is known that each material has different properties, which can be utilized for different applications as per the requirements. In general, metals, such as titanium and stainless steel, and ceramics are the two main materials used in implant fabrication. The alloys of metals are also considered and classified under metallic dental implants. Titanium is used because of its physical properties such as stiffness, which is comparable with bone stiffness, and corrosion resistance properties. Ceramic types are used in creating implants and are considered to be relatively new when compared with metallic implants. Both types have the ability and compatibility with hard tissue and living bones. These materials can be fully integrated with living bones, which is an important factor to ensure osseo-integration so as to have implant stability. Presently, one of the biggest challenges is to select the proper materials for dental implants so as to avoid the conflict between the mechanical properties of engineered and natural biomaterials. This conflict usually produces bone remodeling problems. FGMs have been proposed as an upgraded material that can reduce a lot of these problems. FGMs are materials of two components that have their properties to change gradually over the volume changing from $100 \%$ of one component to grasp $50 \%$ of each component in the middle to finally reach $100 \%$ of the other component in the other side as shown in Figure 1.

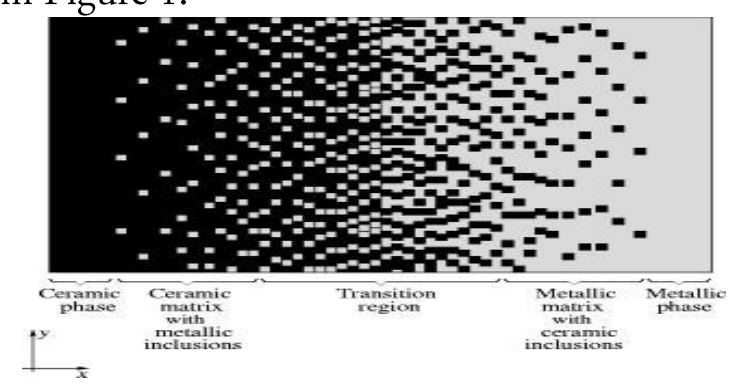

Fig.1. Illustration of Functionally Gradient Material [11].
Many studies have investigated the effect of different gradient composition versus the stress and different geometries shape and style. For the material components in FGM, metalceramic is usually selected for dental implants due to the stiffness property of metals and the ability of bio-ceramic to bond with hard and soft tissues. These studies have showed that FGMs are better and more suitable for dental implants compared with plain metals or ceramic materials. The idea of Functionally Gradient Material FGM used in 1984 in Japan for a space project in which the combination of material is used to withstand the temperature of 2000 Kelvin and a temperature gradient of $1000 \mathrm{k}$ across a 10 $\mathrm{mm}$ section [12]. The biomaterials used in dental implants should have the following properties: biocompatibility, strength, fatigue durability, nontoxicity, corrosion resistance, and sometimes aesthetics [13]. Researchers have investigated and studied the effects of the material type used in dental implants to come up with an optimum material so as to minimize the stresses in the implant and the bone and increase the implant life [14, 15]. It was confirmed that titanium is still considered the main standard for producing dental implants, and the Zirconia implant is promising with a need for more studies focusing on the minimization of mechanical failures [15]. The biomechanical behaviors of FGM in dental implants have been studied and compared [16]. Four models were developed, and 3-D finite elements analysis was accomplished. Two models used titanium with FGM made up of zircon and alumina as the first layer. These two models were compared with a homogeneous zirconia implant. The other two models have varied the amount of $\mathrm{Ti}$ and $\mathrm{HA}$ in the dental implant. The load has been disrupted surrounding the structure (horizontal, vertical, 
and oblique loading), and the results were compared. It was found that the use of FGM material enhanced the distribution of stress and strain compared to the homogeneous materials [16]. The effects of thread dimensions of functionally gradient dental implants on stress distribution leads the equivalent stress to be decreased when the material gradient parameter (n) in FGM increases [17]. A 2-D finite element model using ANSYS was used to overcome the investigation numerically. It was found that the minimum stress distribution increases when the gradient factor " $n$ " increases. The resulting maximum von Mises stress increases when the length of the implant decreases with the thread width kept as constant. They used a technique to assign material properties across the element by applying a spatial continuous variation in the assigned nodal temperature [17]. The effect of soft tissue on the resonance frequency (RF) and the mode shapes of implant were studied numerically and experimentally [18]. The relationship between the strain results on the mandible when a load is applied to a dental prosthesis and implants has also been studied [19].

\section{OBJECTIVE}

FGMs provide the structure with which synthetic biomaterials should essentially be formed. The size of material components is relatively small. In the case of dental applications, the components are generally smaller than $20 \mathrm{~mm}$. The schematic view of FGM dental implant with graded material composition is shown in Figure 2.

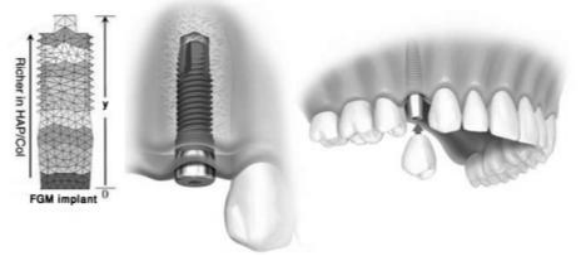

Fig.2. Schematic view of FGM dental implant with gradient material composition [20]
The purpose of this study is to curry out modal analysis numerically for functionally gradient dental implant using ANSYS15.0 APDL. A typical implant schematic is shown in Figure 3. It was required to perform a modal analysis and plot the frequency response of functionally gradient dental implant after performing a static analysis for each modal. In other words, the mechanical behavior of such kind of implant is to be identified. Finally, a comparison between the classical dental implant and the materials utilized in FGM when the ration of each $100 \%$ was performed.

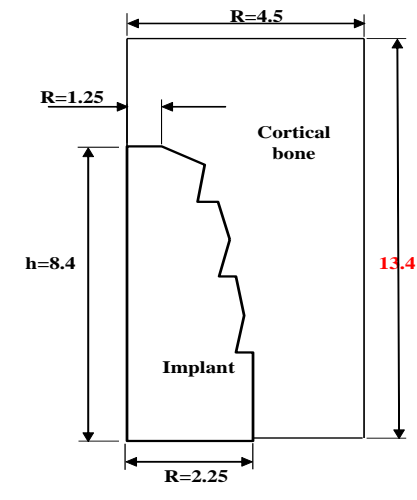

Fig.3. Schematic of implant

\section{MATERIALS AND METHODS}

In this study, a finite element model using ANSYS 15 Mechanical APDL is utilized for the modeling dental implant, as shown in Figure 3, and then simulating the solution numerically. A typical ANSYS analysis process map is shown in Figure 4.

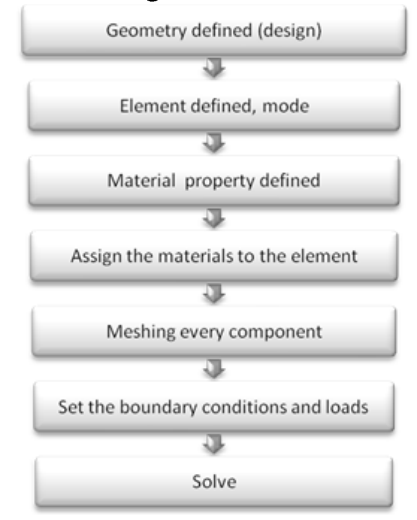

Fig.4. ANSYS analysis process flow chart 
ANSYS models were generated, and the results were compared based on the implant materials. The material property for the cortical bone remains constant (unchanged). On the other hand, the property of implant varies for each model. Table 1 shows the materials mechanical properties of the models.

TABLE 1: MECHANICAL PROPERTIES OF MATERIALS USED FOR THE MODEL

\begin{tabular}{|c|c|c|c|c|}
\hline Material & $\begin{array}{c}\text { Modulus of } \\
\text { elasticity } \\
\text { GPa }\end{array}$ & $\begin{array}{c}\text { Poisson's } \\
\text { ratio }\end{array}$ & $\begin{array}{c}\text { Density } \\
\rho\left(\frac{\mathrm{kg}}{\mathrm{m}^{\mathrm{2}}}\right)\end{array}$ & Reference \\
\hline $\begin{array}{c}\text { Cortical } \\
\text { bone }\end{array}$ & 14 & 0.3 & 1300 & {$[2]$} \\
\hline Titanium & 110 & 0.3 & 4430 & {$[3\}$} \\
\hline $\begin{array}{c}\text { Hydroxya } \\
\text { patite }\end{array}$ & 74 & 0.27 & 3160 & {$[4]$} \\
\hline $\begin{array}{c}\text { Zirconium } \\
\text { Oxide }\end{array}$ & 205 & 0.23 & 5725 & {$[5]$} \\
\hline
\end{tabular}

Zirconium oxide is considered as a classic dental implant material. Since many studies [3-4] have confirmed that titanium and hydroxyapatite (Ti-HA) is optimal when compared with classically used materials, TiHA has been used as an FMG for the implant model as well as separate models. The mechanical properties of the FGM have been calculated using the Excel program. This is to identify Young's Modulus of Elasticity (E), and Poisson ratio $(\vartheta)$ at a certain height.

$$
\begin{gathered}
V_{c}=\left(\frac{y}{h}\right)^{m} \\
V_{m}=1-V_{c} \\
E_{0}=E_{c}\left[\frac{E_{c}+\left(E_{m}-E_{c}\right) V_{m}^{2 / 3}}{E_{c}+\left(E_{m}-E_{c}\right)\left(V_{m}^{\frac{2}{3}}-V_{m}\right)}\right]
\end{gathered}
$$

$$
\vartheta=\vartheta_{m} V_{m}+\vartheta_{c} V_{c}
$$

where:

$E_{0}$ equivalent Young's Modulus at different regions of the implant,

$E_{m}$ Young's Modulus of Elasticity for metal

$E_{c}$ Young's Modulus of Elasticity for ceramic

$V_{c}$ volume fraction for ceramic

$V_{m}$ volume fraction for metal

$h$ total height of the implant

$y$ required calculation height

$\vartheta_{m}$ Poisson ratio for metal

$\vartheta_{c}$ Poisson ratio for ceramic

The ANSYS Mechanical APDL was used for modeling FGMs. PLANE82 2-D 8-Node Structural Solid element was selected as element type for both cortical bone and implant due to its high accuracy of quadrilateral and triangular automatic meshes. In addition, it is well suited to model curved boundaries, as shown in Figure 5.

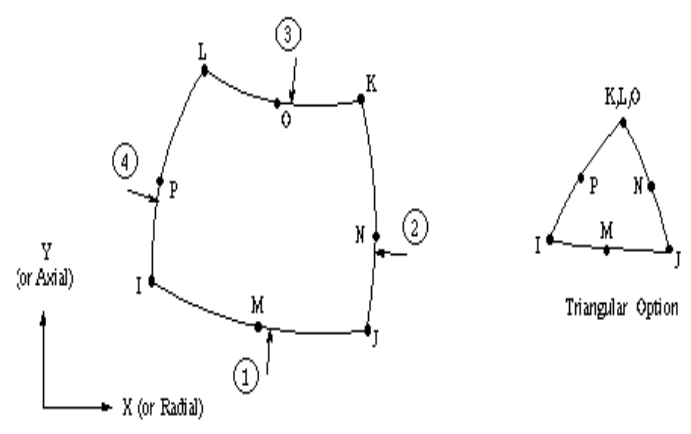

Fig.5. PLANE82 2-D 8-Node Structural Solid 
The implant area was divided into small areas for the loops in ANSYS. Each area is considered as an isotropic. The material property was calculated by Excel program as explained earlier, and then the ANSYS DO loop is used to model the varying material properties of dental implants through the space direction. So, elasticity modulus, density ratio, Poisson ratio, etc. are a function of $y$-direction [21]. The meshing is done with solid elements; the meshed models are shown in Figures 6, 7, and 8. The mesh is refined significantly to capture the accurate result.

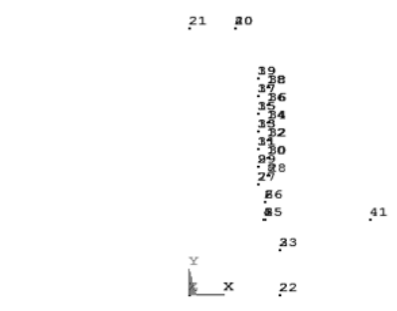

Fig.6. Key points of the implant and cortical bone

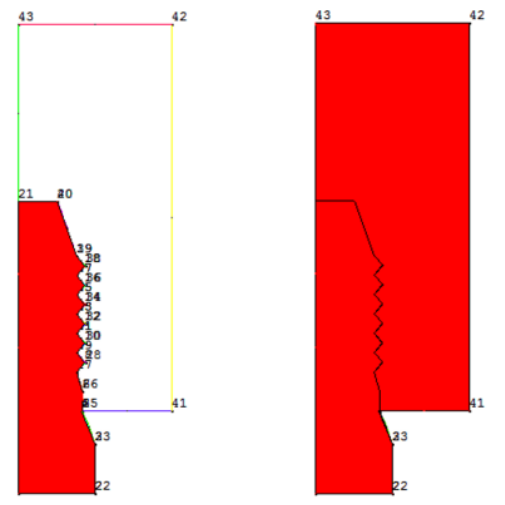

Fig.7. Defined areas of implant and cortical bone.

Modal analysis is carried out for all implant materials specified in Table 2. The modal frequencies are extracted with mode shapes (12 models). The Block Lanczos method is used for the algorithm as it is recommended for most applications. It can extract a large number of modes $(+40)$, and it can be used for complex models with a mixture of solid/shell.
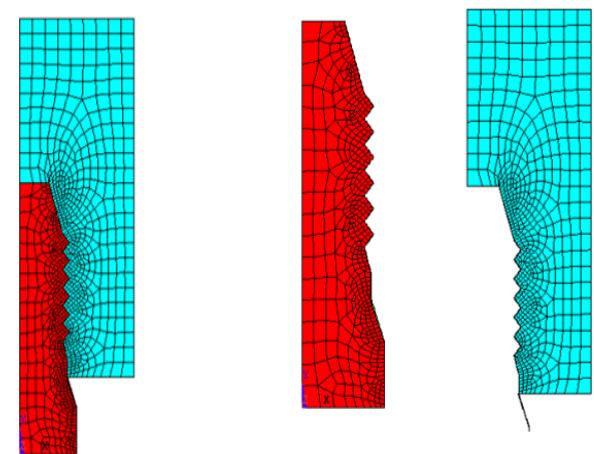

Fig. 8. Meshed model for implant and cortical bone

\section{RESULTS AND DISCUSSIONS}

Mode analysis and harmonic analysis for the five models are discussed in this section. The five models are pure titanium, FGM at $\mathrm{x}=0.01, \mathrm{FGM}$ at $\mathrm{x}=0.5$, pure hydroxyapatite, and zirconium, where $\mathrm{x}$ is a factor to show the effect of increasing radius of the implant. Static analysis was performed for those models. Twelve shape modes are extracted for each. Only the last four deformation shapes are presented. Table 2 shows the mode frequencies for the 12 modes. Figures 10 to 15 display the mode shapes for each material. It can be noticed that the first frequency is zero, which represent the rigid body mode. Hydroxyapatite (ceramic) natural frequency is lower than the titanium natural frequency. It is noted that the frequency of FGM for the implant (Ti-HA) varies between the frequency of two basic materials (hydroxyapatite and titanium). The frequency of FGM is decreased by increasing the content of titanium and vice versa. The frequency of the implant classic marital has a higher frequency compared to all other materials due to its lighter weight. Figure 14 is graphically presenting natural frequencies. Similarly, the deflections which are educed form the deformation shape is slightingly different phenomena of natural frequency. Table 3 displays the deformation shapes for implants in the case of pure titanium, Ti-HA at $\mathrm{x}-0.01$, Ti-HA at $\mathrm{x}=0.5$, pure hydroxyapatite, and 
zirconium. Figure 15 shows that the natural frequency for the pure titanium implant has a higher deformation comparing to other implant materials. For the FGM material, the deformation fluctuates between two basic materials, and it is more near the higher weight of titanium. This is because the content of each FGM is a compound of both materials with a different ratio. A static analysis was carried out for the five models. The von Mises stress and deformation displacement were extruded using static analysis in ANSYS. A $100 \mathrm{~N}$ was applied to the center of the implant in Y-direction (Figure 16). The displacement of the cortical bone was set at zero on the bottom side area. The resulted stress and displacement are summarized in Table 4. It is clear that the stress increases with an increase in rigidity of the implant material. The zirconium implant has the highest stress with $15.548 \mathrm{MPa}$ and lower displacement at $0.00096 \times 10^{\wedge}-5 \mathrm{~mm}$. The FGM implant materials stress is higher when $x=0.01$ and lower when $x=0.5$. When the amount of $\mathrm{Ti}$ increases, the stress will increase, and the displacement will decrease. It is observed that hydroxyapatite has a lower stress and higher displacement. This is because it is softer and more flexible when compared to other materials. Figures 17-21 represent the nodal solution and displacement deformed shape for the five models. To plot the frequency response of the system, the harmonic analysis was performed for all five models. The number of sub-steps was selected to be 100 . The force of $100 \mathrm{~N}$ was set in Ydirection at the center of the bone area. The frequency range was set between 0-6000 Hz. Tow nodes were selected on the implant to extrude the frequency for each model. Figures 22-26 show the frequency response with the amplitude at Y-direction. The performed harmonic analyses have been carried out for the specified two nodes. Thus, the resulted plots can provide the deflection in those nodes at a certain frequency. It is clear that the FGM is moving similar to the titanium but with a lower deflection.

TABLE 2: FREQUENCIES FOR 12 MODE SHAPES

\begin{tabular}{|c|c|c|c|c|c|}
\hline \multirow{2}{*}{$\frac{\tilde{g}}{\dot{0}}$} & Pure & $\begin{array}{l}\text { FGM at } \\
x=0.01\end{array}$ & $\begin{array}{c}\text { FGM } \\
\text { at } \\
x=0.5\end{array}$ & Pure & $\begin{array}{l}\text { Classic } \\
\text { implant }\end{array}$ \\
\hline & 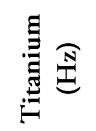 & $\underset{1}{S}$ & 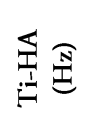 & 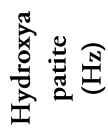 & 莺 \\
\hline 1 & $3.41 e^{-5}$ & 0 & 0 & 0 & 0 \\
\hline 2 & 266 & 266.01 & 264.75 & 258.51 & 319.9 \\
\hline 3 & 527.29 & 527.33 & 502.52 & 515.88 & 643.9 \\
\hline 4 & 633.28 & 633.71 & 537.35 & 610.25 & 746.89 \\
\hline 5 & 697.75 & 698.22 & 644.42 & 682.72 & 851.68 \\
\hline 6 & 823.53 & 823.96 & 741.97 & 800.96 & 985.84 \\
\hline 7 & 907.26 & 908.16 & 797.69 & 870.85 & 1057.2 \\
\hline 8 & 973.63 & 974.94 & 808.16 & 929.31 & 1109.2 \\
\hline 9 & 986.77 & 987.76 & 846.26 & 943.88 & 1157.3 \\
\hline 10 & 998.23 & 999.36 & 923.1 & 963.48 & 1172.6 \\
\hline 11 & 1084.9 & 1086.1 & 944.05 & 1037.9 & 1262.9 \\
\hline 12 & 1108.7 & 1110.1 & 979.46 & 1060.8 & 1298.7 \\
\hline
\end{tabular}

TABLE 3: DEFORMATION SHAPES FOR IMPLANTS

\begin{tabular}{|c|c|c|c|c|c|}
\hline \multirow[b]{2}{*}{$\frac{\ddot{Z}}{\dot{0}}$} & Pure & $\begin{array}{c}\text { FGM at } \\
x=0.01\end{array}$ & $\begin{array}{c}\begin{array}{c}\text { FGM at } \\
\mathrm{x}\end{array}=0.5\end{array}$ & Pure & $\begin{array}{c}\text { Classic } \\
\text { implant }\end{array}$ \\
\hline & 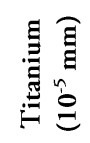 & 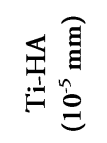 & 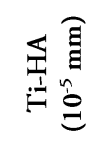 & 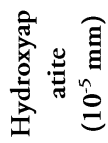 & 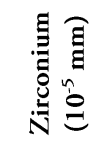 \\
\hline 1 & 1.4951 & 1.4977 & 1.2581 & 1.7702 & 1.3151 \\
\hline 2 & 2.5112 & 2.5144 & 2.0981 & 2.9738 & 2.2082 \\
\hline 3 & 3.0942 & 3.1007 & 2.4158 & 3.6965 & 2.7766 \\
\hline 4 & 5.4006 & 5.4135 & 4.3662 & 6.4776 & 4.8670 \\
\hline 5 & 3.2291 & 3.2358 & 2.5205 & 3.7606 & 2.7382 \\
\hline 6 & 3.0023 & 3.0135 & 2.8483 & 3.4633 & 2.4279 \\
\hline 7 & 3.0551 & 3.0583 & 3.8684 & 3.5825 & 2.6522 \\
\hline 8 & 4.6928 & 4.6886 & 3.4777 & 4.4889 & 2.7607 \\
\hline 9 & 3.7743 & 3.7676 & 3.2304 & 4.2164 & 2.5737 \\
\hline 10 & 4.0988 & 4.1163 & 3.5235 & 4.5863 & 2.9777 \\
\hline 11 & 3.0822 & 3.0371 & 3.9301 & 4.8428 & 4.2740 \\
\hline 12 & 4.0733 & 4.0844 & 4.2642 & 4.8058 & 4.5424 \\
\hline
\end{tabular}


TABLE 4: VON MISES STRESS AND DISPLACEMENT FOR STATIC ANALYSIS MODELS

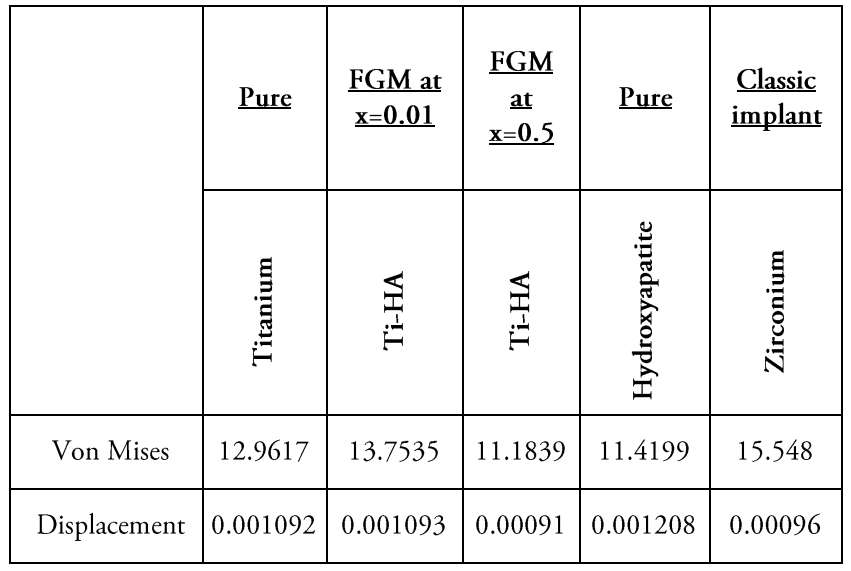

Mode 1

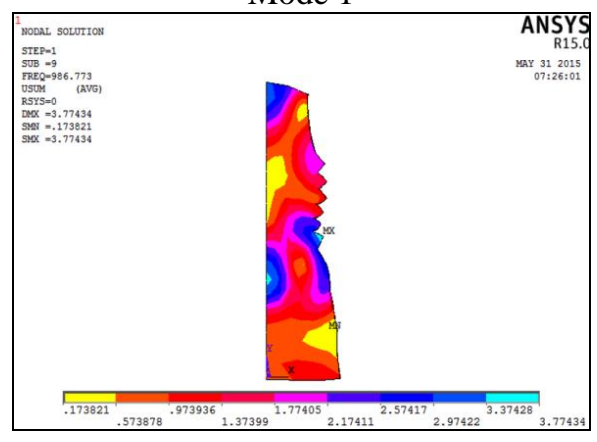

Mode 3

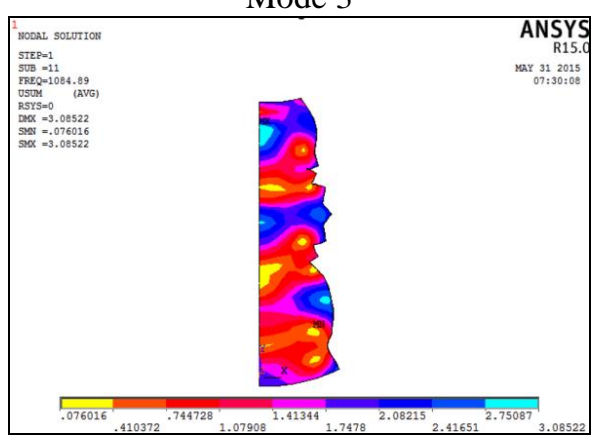

Mode 2

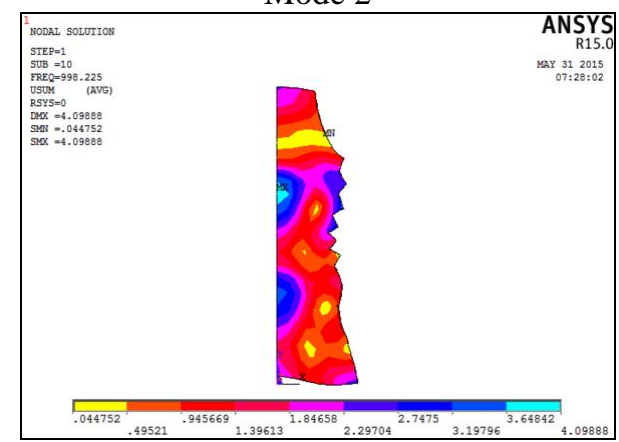

Mode 4

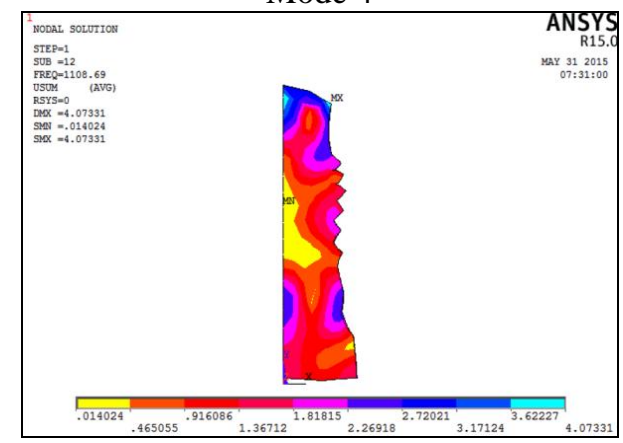

Fig.9. Mode shapes for (Titanium) 
Mode 1

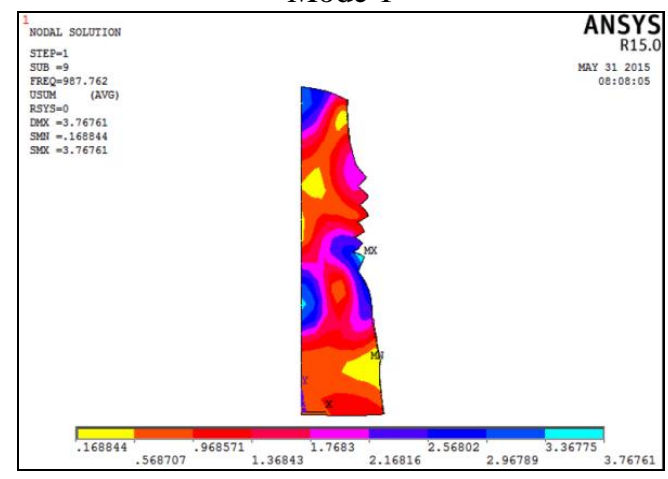

Mode 3



Mode 2

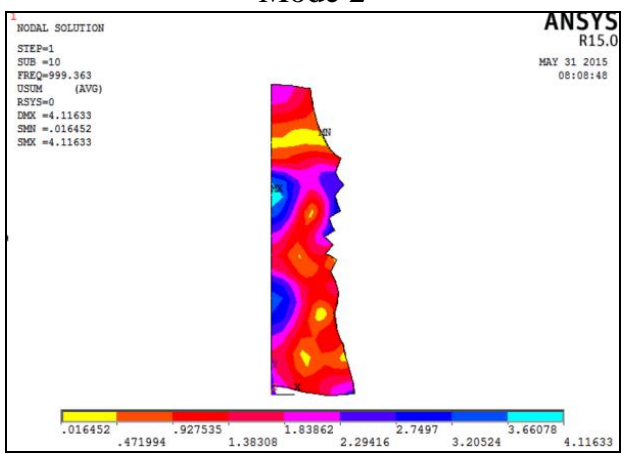

Mode 4

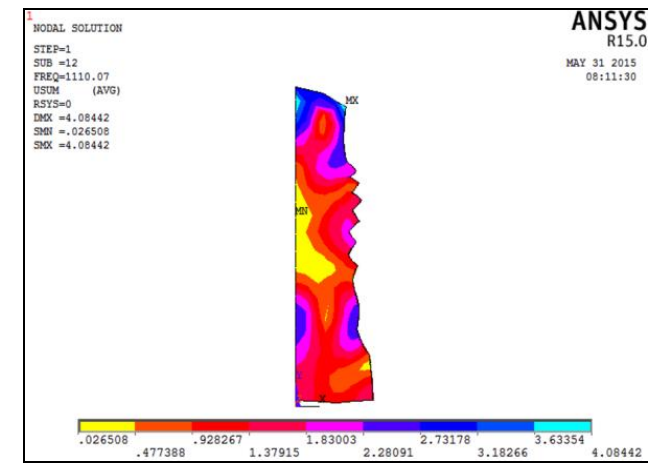

Fig.10. Mode shape (FGM Ti-HA) at $\mathrm{x}=0.01$

Mode 1

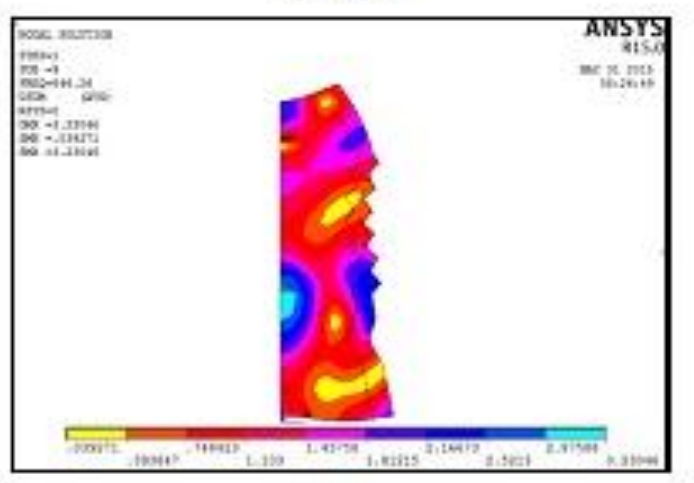

Mode 3

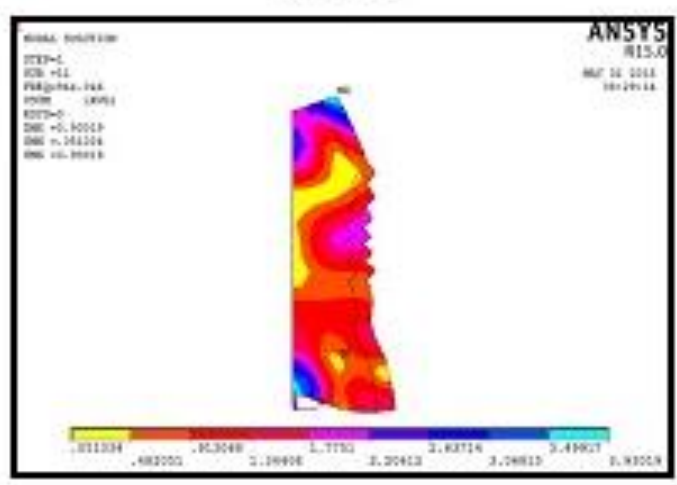

Mode 2

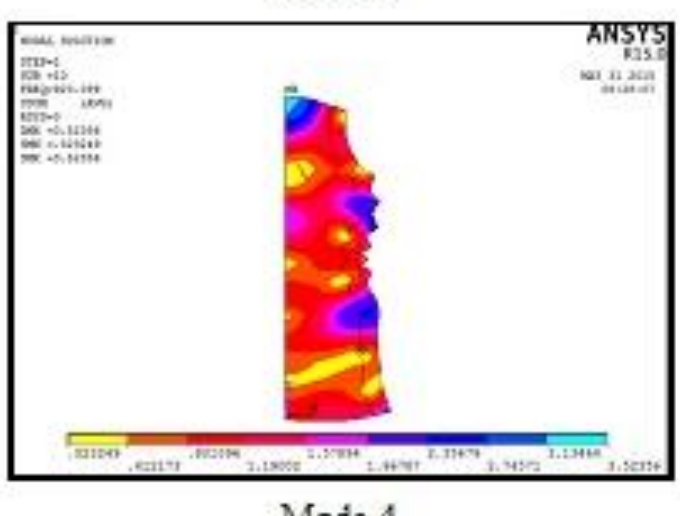

Mode 4

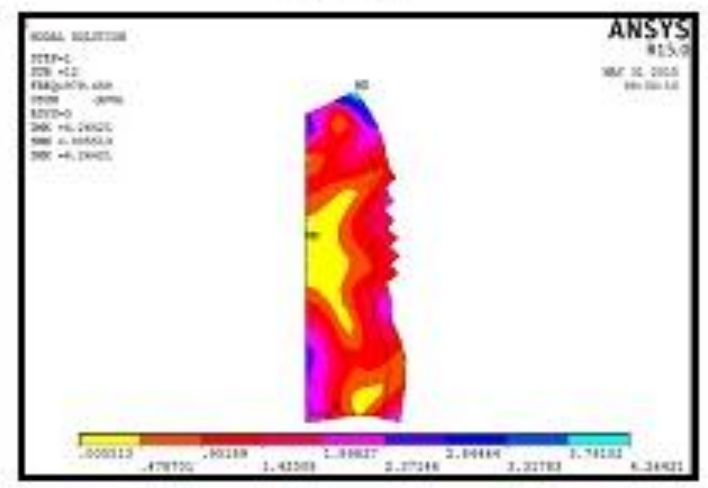

Fig.11. Mode shape (FGM Ti-HA) at $\mathrm{x}=0.5$ 
Mode 1

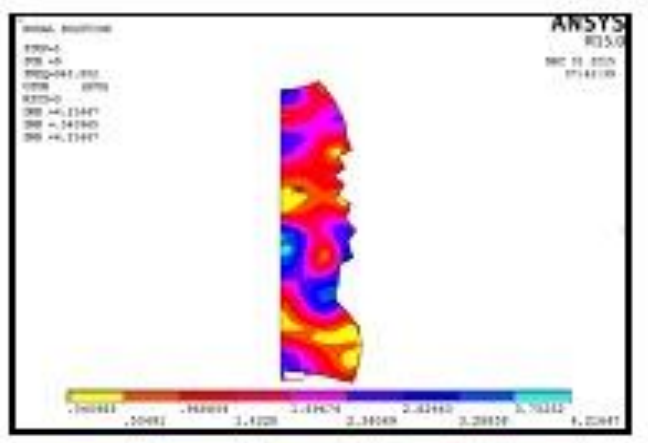

Mode 3

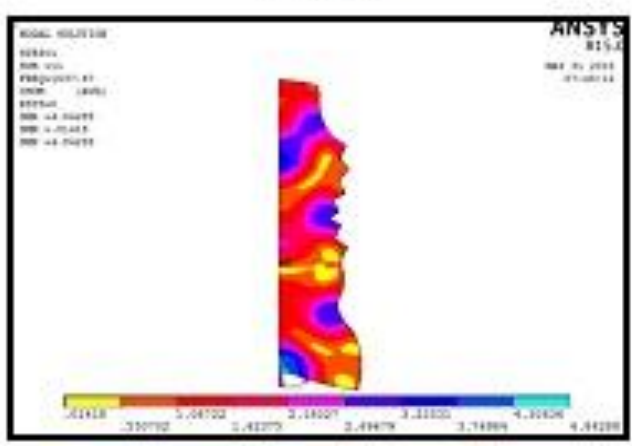

Fig.12. Mode shape Hydroxyapatite
Mode 2

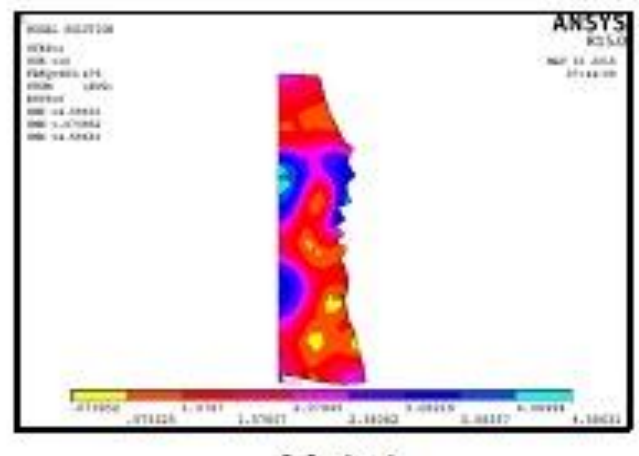

Mode 4

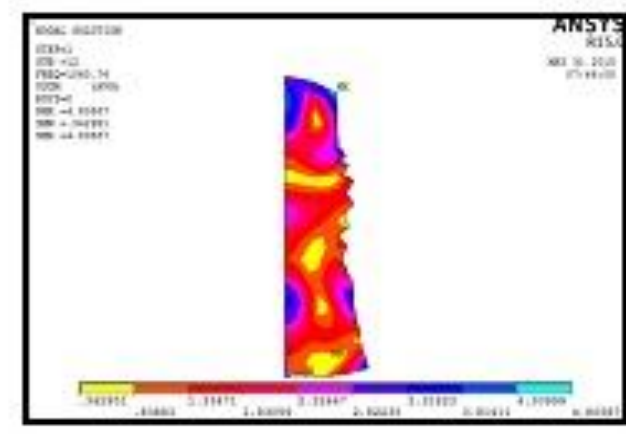

Mode 2

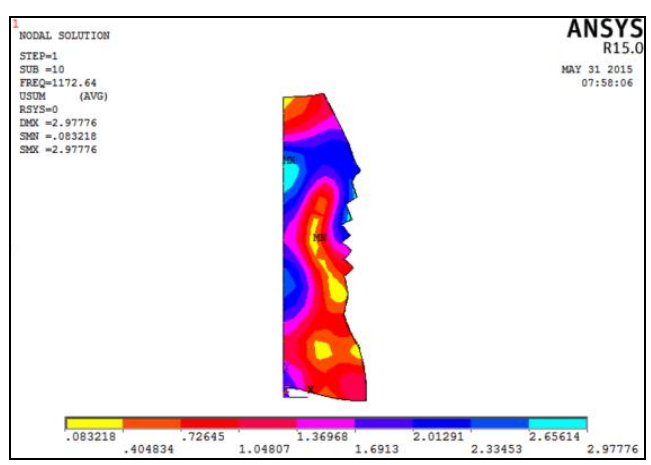

Mode 4

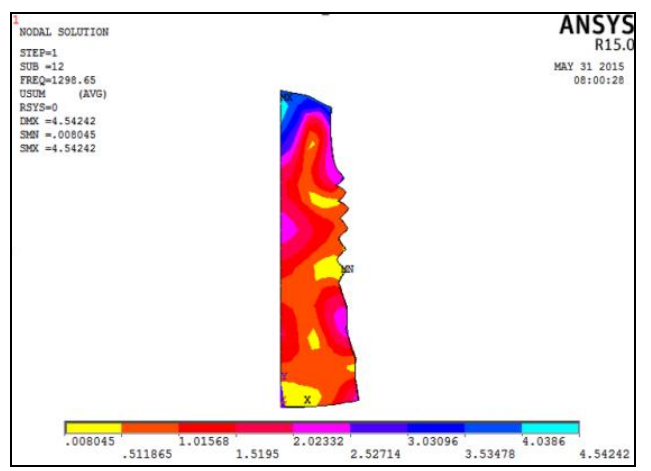

Fig.13. Mode shape for Zirconium Oxide 


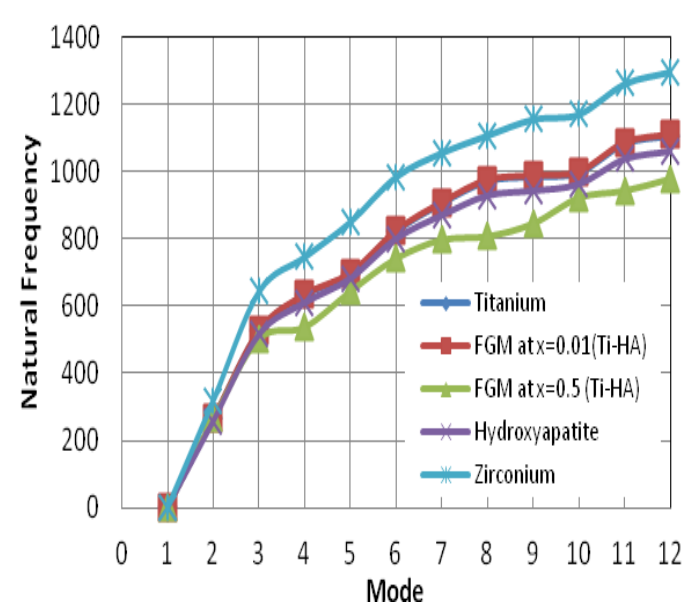

Fig.14. Natural frequencies for 12 mode shapes

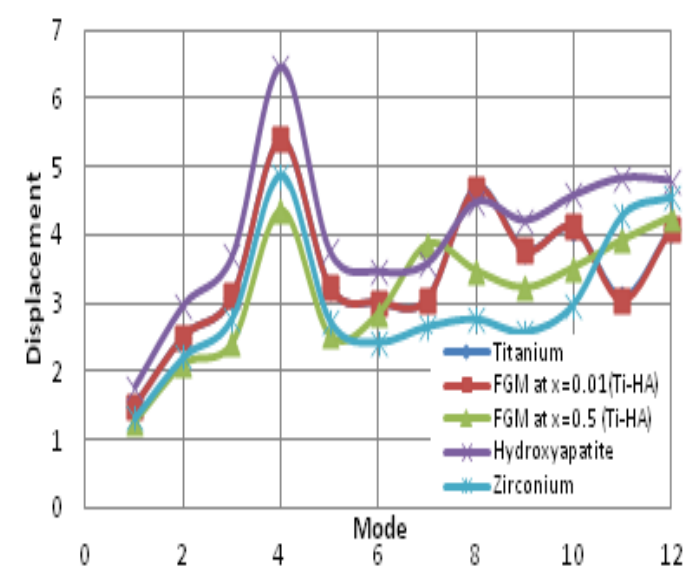

Fig.15. Maximum displacements of deformed shape for the first 12 mode shapes

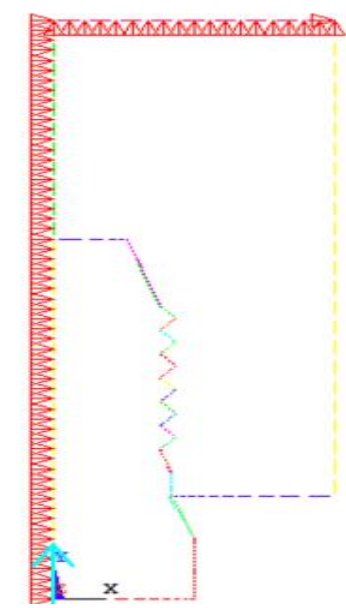

Fig.16. $100 \mathrm{~N}$ is applied in Y-direction (static analysis)

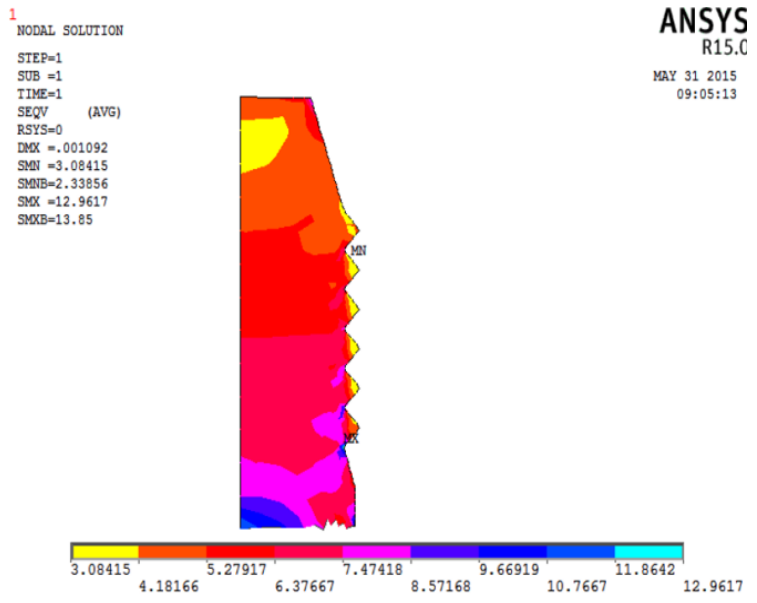

Fig.17. Static deformation for (Titanium)

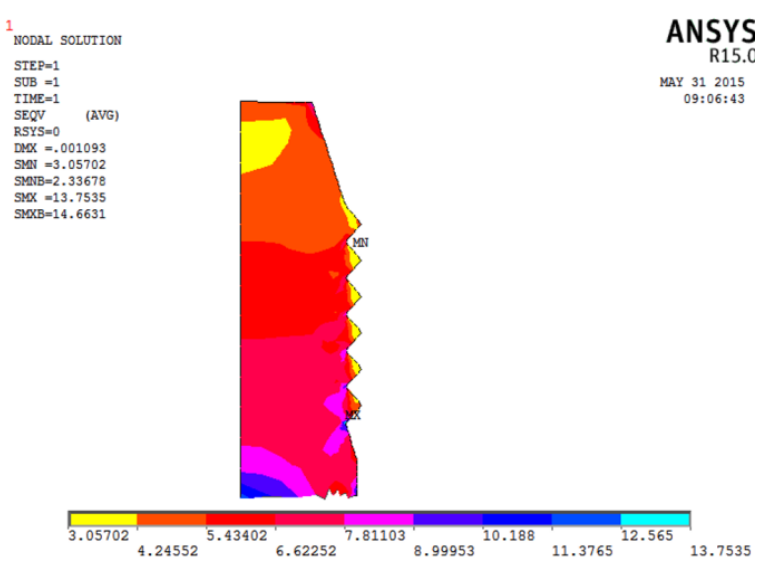

Fig.18. Static deformation (FGM Ti-HA)at $\mathrm{x}=0.01$ )

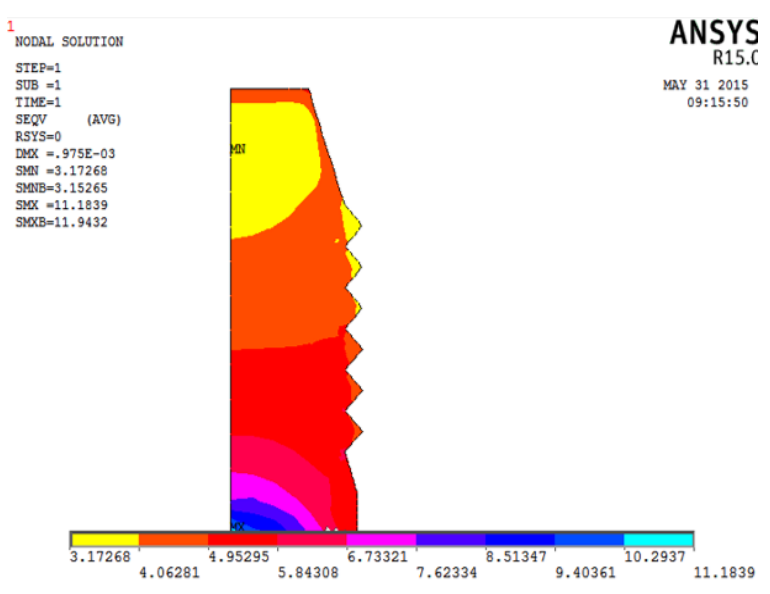

Fig.19. Static deformation for (FGM Ti-HA)at $\mathrm{x}=0.5$ 


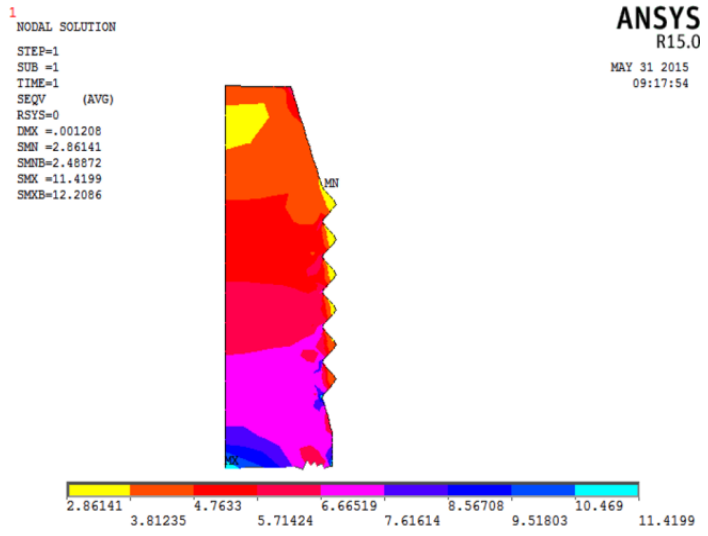

Fig.20. Static deformation for Hydroxyapatite

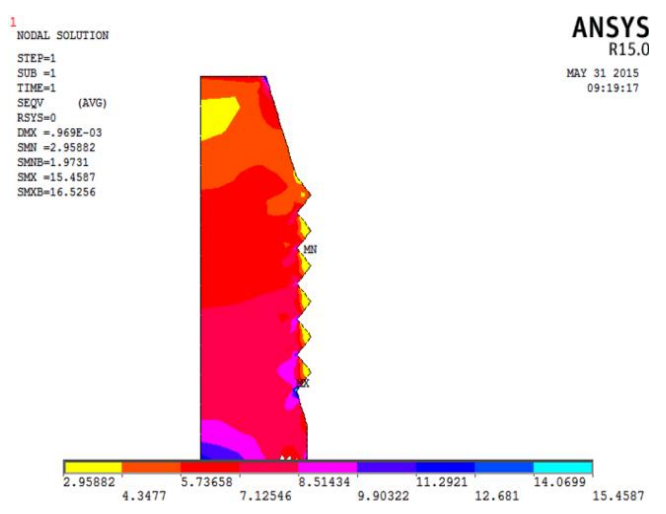

Fig.21. Static deformation for Zirconium Oxide

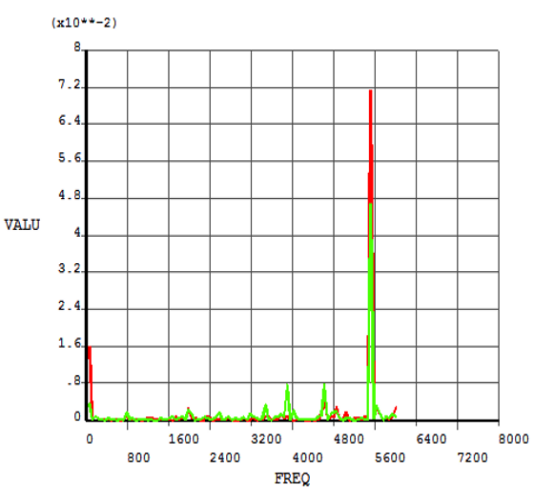

Fig.22. Frequency response for Titanium

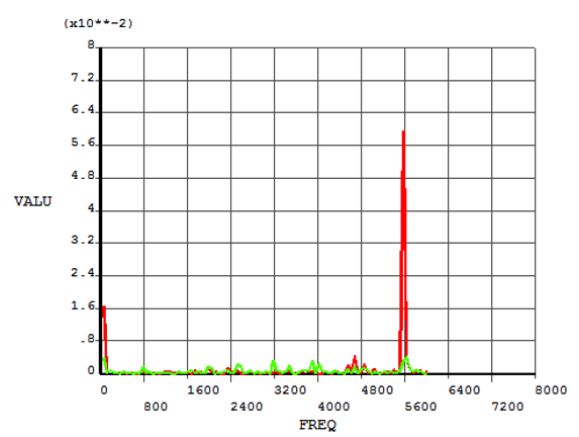

Fig.23. Frequency response for FGM Ti-HA at $\mathrm{x}=0.01$

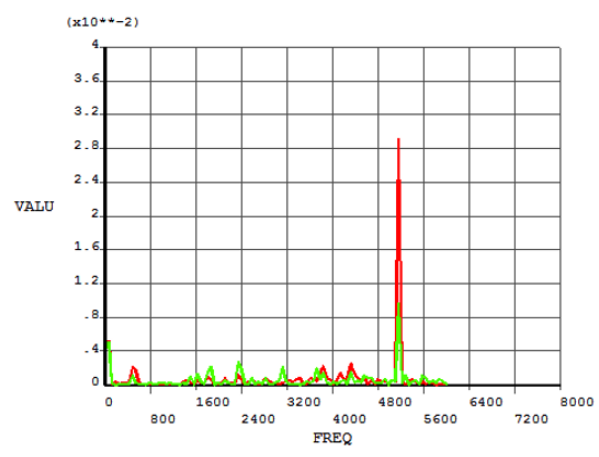

Fig.24. Frequency response for FGM Ti-HA at $\mathrm{x}=0.5$

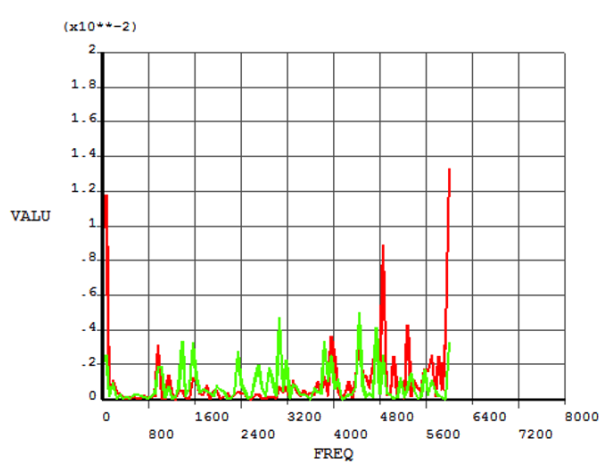

Fig.25. Frequency response for Hydroxyapatite

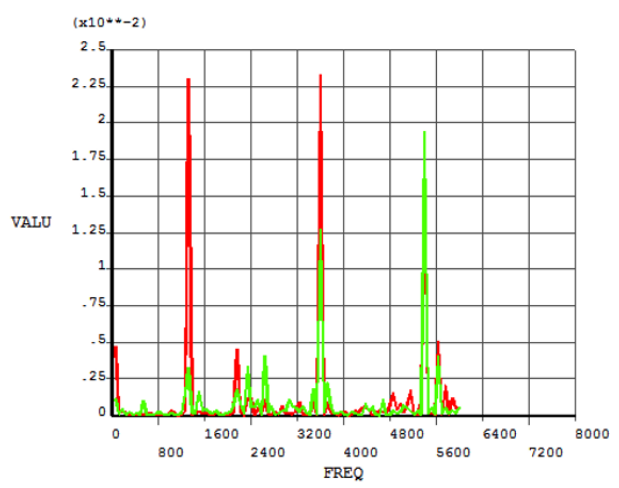

Fig.26. Frequency response for Zirconium

\section{CONCLUSIONS}

In this study, several models for dental implant were analyzed by ANSYS15.0 APDL. The FGM was considered in two models using ANSYS15.0 APDL. Both were for the same materials, Ti-HA with different diameter increments. The natural frequency and modal shapes were extracted for all models. Generally, it was noticed that the natural frequency, modal shape, stresses, and displacement vary between the two basic materials in the FGM dental implant but are nearer to the titanium. 
It strongly depends on the concentration of the material in the model. When the ration for the titanium increases for the FGM implant, the frequency decreases due to the higher weight and vice versa. There is a need for future research works on the dental implants to be optimized in the case of FGM. The tools for designing and simulating the desired material property are available on hand that will help to have a more stable, safe, and cost-effective dental implant.

\section{REFERENCES}

[1] Plikçiolu, H., and Akça, K., Comparative evaluation of the effect of diameter, length and number of implants supporting three-unit fixed partial prostheses on stress distribution in the bone. Journal of Dentistry, 30(1), 41-46, 2002.

[2] Pierrisnard, L., Renouard, F., Renault, P., and Barquins, M., Influence of implant length and bicortical anchorage on implant stress distribution. Clinical Implant Dentistry Related Research, 5(4), 254-262, 2003.

[3] Yokoyama, S., Wakabayashi, N., Shiota, M., and Ohyama, T., The influence of implant location and length on stress distribution for three-unit implant-supported posterior cantilever fixed partial dentures. Journal of Prosthetic Dentistry, 91(3), 234-240, 2004.

[4] Aparicio, C., and Orozco, P., Use of 5-mmdiameter implants: Periotest values related to a clinical and radiographic evaluation. Clinical Oral Implants Research, 9(6), 398-406, 1998.

[5] Iplikcioglu, H., and Akca, K., 2002, Comparative evaluation of the effect of diameter, length and number of implants supporting three-unit fixed partial prostheses on stress distribution in the bone. Journal of Dentistry, 30(1), 41-46.

[6] Ivanoff, C.J., Grondahl, K., Sennerby, L., Bergstrom, C., and Lekholm, U., Influence of variations in implant diameters: a 3- to 5-year retrospective clinical report. International Journal of Oral Maxillofacial Implants, 14(2), 173-180, 1999.

[7] Misch, C.E., Implant design considerations for the posterior regions of the mouth. Implant Dentistry, 8(4), 376-386, 1999.
[8] Tawil, G., Mawla, M., and Gottlow, J., Clinical and radiographic evaluation of the $5-\mathrm{mm}$ diameter regular-platform Branemark fixture: 2to 5-year follow-up. Clinical Implant Dentistry Related Research, 4(1), 16-26, 2002.

[9] Zhang, L., Zhou, Y., and Meng, W., A threedimensional finite element analysis of the correlation between lengths and diameters of the implants of fixed bridges with proper stress distribution. Hua Xi Kou Qiang Yi Xue Za Zhi, 18(4), 229-231, 2000.

[10] Astrand, P., Billstrom, C., Feldmann, H., Fischer, K., Henricsson, V., Johansson, B., Nystrom, E., and Sunzel, B., Tapered implants in jaws with soft bone quality: a clinical and radiographic 1year study of the Branemark System Mark IV fixture. Clinical Implant Dentistry Related Research, 5(4), 213-218, 2003.

[11] Y. Chan, G. Paulino and A. Fannjiang, Fracture in Functionally Graded Materials-Part II: Crack Parallel to the Material Gradation, Journal of Applied Mechanics, 75(6), 2008.

[12] N. Noda, Thermal stresses in functionally graded materials, Journal of Thermal Stresses, 22, 477512, 1999.

[13] F. Watari, A. Yokoyama, F. Saso, M. Uo, T. Kawasaki, Fabrication and properties of functionally graded dental implant, Composites Part B, 5-11, 1997.

[14] H.S. Hedia and N. A. Mahmoud, Design optimization of functionally graded dental implant, J. Bio-Medical Materials and Engineering, 14(2), 133-143, 2004.

[15] R. B. Osman and Michael V. Swain, A Critical Review of Dental Implant Materials with an Emphasis on Titanium versus Zirconia, Materials Journal, 8(3), 932-958, 2015.Brudeli, B., Moltzau, L. R., Andressen, K. W., Krobert, K. A., Klaveness, J., Levy, F. O., Synthesis and pharmacological properties of novel hydrophilic 5-HT4 receptor antagonists, Bioorg. Med. Chem., 8(24), 8600-8613, 2010.

[16] N. H. Abu Kasim, A. A. Madaf, M. Hamdi and R. Ghahnavyeh, 3D-FE analysis of functionally graded structured dental posts, Dental Materials Journal, 30(6), 869-880, 2011.

[17] M. Kaman and N. Celik, Effects of Thread Dimensions of Functionally Graded Dental Implants on Stress Distribution, World Academy 
of Science, Engineering and Technology, 78, 2013.

[18] R. Harirforoush, Dental implant stability analysis by using resonance frequency method, M.Sc., Islamic Azad University, 2003.

[19] João Paulo Dias Andrade, Biomechanical Simulation of the Load Distribution in Dental Implants, PhD Thesis. Universidade do Porto, 2013.

[20] A. Sadollah, A. Bahreininejad, Optimum gradient material for a functionally graded dental implant using metaheuristic algorithms, Journal of the Mechanical Behavior of Biomedical Materials, 4(7), 1384-1395, 2011.
[21] Nemat-Alla, M, "Volume fraction, rule of mixture and thermal stresses for 2-d functionally graded material" Third Assiut University Int. Conf. On Mech. Eng. Advanced Tech. For Indus. Prod. December 24-26, 2002.

[22] J. B. Park and R. S. Lakes, Biomaterials: an introduction, Springer Science \& Business Media, 2007.

[23] ANSYS2015 user manual

[24] http://www.ansys.stuba.sk. 2014. 4.83 PLANE83 8-Node Axisymmetric-Harmonic. [ONLINE] Available at: http://www.ansys.stuba.sk/html/elem_55/chapter 4/ES4-83.htm. [Accessed 31 May 15] 


\section{تحليل الإهتزازات لعملية زرع الأسنان بإستخذام المواد المتدرجة وظيفياً

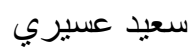 \\ قسم الهنسة الميكانيكية - كلية الهنسة - جامعة الملك عبدالعزيز - المملكة العربية السعودية}

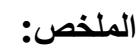

تعتبر زراعة الأسنان أفضل علاج في حالة فقد الأسنان، حيث أنها تعطي نتائج باهرة ويمكن أن تستمر لفتر ات أطول من معظم العلاجات الأخرى. وحيث أن فترة الإلتحام التكاملي هي فترة حاسمة لإستقر ار وثبات عملية الزرع، فإن المواد المستخدمة لزر اعة الأسنان تمثل واحدة من أهم العوامل التي تؤثر على إستقرار وثبات عملية الزرع ولذلك فإن إستخدام المواد المتدرجة وظيفياً (FGM) تمثل واحدة من الفرص لتحسين الإستقرار.

في هذه الدراسة تم تحليل عدة نماذج لزراعة الأسنان بو اسطة ANSYS15.0 APDL وتم إختيار المادة المتدرجة وظيفياً في ثناثة نماذج وجميعها تستخدم نفس النوع من المو اد وهي -Ti ولكن مع أشكال هندسية مختلفة. تم إستتناج التردد الطبيعي والأشكال النموذجية لجميع النماذج وبعد ذلك تم إجراء التحليل التو افقي لدر اسة التحليل الترددي لنماذج مختلفة. وقد لوحظ من كل النتائج ان المواد المتدرجة وظيفياً تختلف بين المادتين الأساسيتين وتتأثر بتركيز كل منها. من خلال هذه الدراسة يمكن التأكيد على أن المواد المتدرجة وظيفياً FGM هي مستقبل زر اعة الأسنان بسبب القدرة الفائقة على تصميم مواد ذات خصائص محددة وتكون أكثر 